\title{
Development and validation of the Perceived Influences on Sport and Study Assessment Scale
}

\author{
Larissa Fernanda Porto Maciel $^{1}$ (D), Mônica Cristina Flach (D) \\ Santa Catarina State University, Florianópolis-SC, Brazil \\ William das Neves Salles(D), Ricardo Teixeira Quinaud(D), Juarez Vieira do Nascimento(D) \\ Federal University of Santa Catarina, Florianópolis-SC, Brazil \\ Alexandra Folle (iD \\ Santa Catarina State University, Florianópolis-SC, Brazil
}

\section{ABSTRACT}

The objective of this cross-sectional study was to develop and validate an Assessment Scale for Perceived Influences in Sport and Study (EIPE). The validation process was carried out with specialists and athletes of both sexes, from team and individual sports, aged between 13 and 18 years old and who attended secondary and high school Education in Santa Catarina/Brazil. Five steps were taken in order to validate the instrument: content validity; clarity of language; pilot test; construct validity; internal consistency; and reliability. Results showed that the final version of the EIPE (two factors and 49 items) showed satisfactory adjustment indices $\left(\chi^{2} / g l=1.751 ; \mathrm{GFI}=.85 ; \mathrm{AGFI}=.82 ; \mathrm{CFI}=.90 ; \mathrm{SRMR}=.059 ; \mathrm{RMR}=.046 ; \mathrm{RMSEA}=.042 ; \mathrm{CFI}=.90 ; \mathrm{TLI}=.89\right)$, high internal consistency $(\alpha>.70)$ and reliability $(\alpha>$.91). It is concluded that the EIPE has satisfactory psychometric properties that provide evidence of scientific validity and reliability.

Keywords: athletes; students; psychometrics; factor analysis.

RESUMO - Desenvolvimento e Validação da Escala de Avaliação de Influências Percebidas no Esporte e no Estudo O objetivo desse estudo foi desenvolver e validar uma Escala de Avaliação de Influências Percebidas no Esporte e no Estudo (EIPE). O processo de validação foi realizado com especialistas e atletas de ambos os sexos, com idade entre 13 e 18 anos e que cursavam a Educação Básica em Santa Catarina/Brasil. Cinco etapas foram realizadas para validar o instrumento: validade de conteúdo; clareza de linguagem; teste de piloto; validade do construto; consistência interna; e fidedignidade. Os resultados mostraram que a versão final da EIPE (dois fatores e 49 itens) apresentou índices de ajuste satisfatórios $\left(\chi^{2} / g l=1,751 ; \mathrm{GFI}=0,85 ; \mathrm{AGFI}=0,82 ; \mathrm{CFI}=0,90\right.$; $\mathrm{SRMR}=0,059 ; \mathrm{RMR}=0,046 ; \mathrm{RMSEA}=0,042 ; \mathrm{CFI}=0,90 ; \mathrm{TLI}=0,89)$, alta consistência interna $(\alpha>0,70)$ e fidedignidade $(\alpha>0.91)$. Conclui-se que a EIPE possui propriedades psicométricas aceitáveis que fornecem evidências de validade e confiabilidade científica. Palavras-chave: atletas; estudantes; psicometria; análise fatorial.

RESUMEN - Desarrollo y validación de la Escala de Evaluación de Influencias Percibidas en el Deporte y en el Estudio El objetivo de este estudio fue desarrollar y validar una Escala de evaluación de las influencias percibidas en el deporte y el estudio (EIPE). El proceso de validación se llevó a cabo con especialistas y atletas de ambos sexos, con edades entre 13 y 18 años, que estudiaban Educación Básica en Santa Catarina/Brasil. Se dieron cinco pasos para validar el instrumento: validez de contenido; claridad del lenguaje; prueba piloto; validez de constructo; consistencia interna; y fiabilidad. Los resultados mostraron que la versión final del EIPE (dos factores y 49 ítems) mostró índices de ajuste satisfactorios $\left(\chi^{2} / g l=1.751 ; \mathrm{GFI}=.85 ; \mathrm{AGFI}=.82 ; \mathrm{CFI}=.90\right.$; $\mathrm{SRMR}=.059 ; \mathrm{RMR}=.046 ; \mathrm{RMSEA}=.042 ; \mathrm{CFI}=.90 ; \mathrm{TLI}=.89)$, alta consistencia interna $(\alpha>.70)$ y fiabilidad $(\alpha>.91)$. Se concluye que el EIPE tiene propiedades psicométricas aceptables que proporcionan evidencia de validez y confiabilidad científica.

Palabras clave: atletas; estudiantes; psicometría; análisis factorial.

\section{Perceived Influences on Sport and Study}

In the scenario of scientific research conducted with young athletes, it is important to understand both personal and social factors capable of influencing the developmental processes in sports and school. The use of valid questionnaires, that allow a broad understanding of specific contexts, is a well-known technique to obtain

Correspondence address: Health and Sports Science Center - CEFID, Santa Catarina State University - UDESC. Pascoal Simone Street, 358 - Coqueiros, Florianópolis, SC, Brazil, 88080-350. Phone.+55 (48) 98429-2868.E-mail: larissa maciel10@edu.udesc.br

This study was financed in part by the Coordenação de Aperfeiçoamento de Pessoal de Nível Superior - Brasil (CAPES) - Finance Code 001 and by the Santa Catarina State Research and Innovation Support Foundation (FAPESC/UDESC), under the number PAP2019031000011.

Artigo derivado da Dissertação de mestrado da Larissa Fernanda Porto Maciel com orientação da Professora Dra. Alexandra Folle, defendida em 2019, no Programa de Pós-graduação em Ciências do Movimento Humano da Universidade do Estado de Santa Catarina. 
reliable data. Because of that, assessment instruments need to follow a process that goes from constructing their dimensions and components to ascertaining their validity and reliability (Drost, 2011; Hernández-Sampieri et al., 2014) before being applied to the target population (Collet et al., 2019).

Millions of children and adolescents around the world are involved in sports (Ramey, \& Rose-Krasnor, 2012), while going through the schooling process. The simultaneous influence of sports activities with school duties is a subject that has aroused the research interest over the years (Carreres-Ponsoda et al., 2012), mainly because both sports and school can play significant roles in human development (Milistetd et al., 2008).

In the youth sport context, because the athletes need to adapt themselves to new environments and deal with simultaneous challenges in sports and school, they should develop specific skills that support their trajectories. Holt and Dunn (2004) suggest four competencies capable of influencing the athlete's personal engagement in sporting activities, which can be equally extended to school activities: discipline (displaying disciplined behaviours and dedication to deal with challenges in practices and routines); commitment (displaying intrinsic motivation that supports the pursuit of a sports career); resilience (recovering from personal and contextual adversity and obstacles); and social support (perceiving and using available sources of support).

As athletes progress in their sporting career, the support of those closest to them - such as family members, coaches, and teammates - is critical to sport engagement (Côté et al., 2003) since they correspond to the athlete's main motivators and influencers in sport and school. Athlete-student life has additional demands that require extra attention (O'Neill et al., 2015) and unique forms of support such as motivation (emotional support) - perceived incentive in interpersonal relationships; guidance (informational support) - advices, tips and guidance for problem-solving; and concrete assistance (tangible support) - financial and logistical help to deal with problems and difficulties) (Cutrona, \& Russel, 1990; Holt, \& Dunn, 2004).

In the sports literature, there are some valid instruments that aim to analyse factors that may affect the athletes' developmental process, such as the Social Provisions Scale (Cutrona, \& Russell, 1987); the Social Support Questionnaire (Sarason et al., 1987); and the PASS-Q: The Perceived Available Support in Sport Questionnaire (Freeman et al., 2011). There are also instruments aimed to understand the athletes' perceptions regarding the influence of other social agents, such as the Peer Motivational Climate in Youth Sport Questionnaire (Ntoumanis, \& Vazou, 2005); the Parental Behaviours in Sport Questionnaire (Gomes, \& Zão, 2007); Parental Involvement in Sport Questionnaire (Lee, \& MacLean, 1997); and the Coach-Athlete Relationship Questionnaire (Jowett, \& Ntoumanis, 2004).
In the Brazilian context, there is a lack of research on the analysis of the social agents' influence on the athletes' lives, as well as regarding the observation of sports and academic elements together, with few validated and published instruments. Most of these instruments were built only for specific research purposes (Peserico et al., 2015; Soares et al., 2015; Maciel et al., 2017; O'Neill et al., 2015), making its applicability to other contexts very limited. Thus, considering the absence of contextually specific and psychometrically adequate instruments for collecting information that consider the young athletes' perceptions on the influences of personal sickness and the support of social agents, the objective of our investigation was to develop and validate a scale for the assessment of perceived influences in sport and study for athletes from sports training categories.

\section{Method}

\section{Initial scale construction}

The Perceived Influences in Sport and Study Assessment Scale, originally (Portuguese) named Escala de Influências Percebidas no Esporte e no Estudo (EIPE; supplement A) aims to analyse the athletes' perceptions regarding the influence of both personal and social agents' engagement in sports and study. The theoretical references that support the development of EIPE were the Theory of Psychosocial and Environmental Competences, proposed by Holt and Dunn (2004), and the social influences suggested by Côté et al. (2003).

The scale includes the perceived influences on sport and school from two factors: 1. Involvement in sports training and sports performance in competitions; and 2. Involvement in studies and school performance. The scale was initially composed of 64 items. The items were built based on indicators linked to personal engagement and the influence of social agents (family members, coaches, teammates). Each of these factors was composed of 16 items, answered according to a scale ranging from 1 (very negative influence) to 5 (very positive influence).

The indicators (items) regarding personal engagement corresponded to: (a) discipline (dedication, responsibility); (b) commitment (goals, the pursuit of sports and school career); and (c) resilience (recovery from adversity and obstacles). The indicators related to the influence of social agents (family members, coaches, and teammates) (Côté et al., 2003) were based on three types of social support: emotional (incentive, motivation); informative (tips, guidelines); and tangible (transportation, materials) (Holt, \& Dunn, 2004). Additionally, the development of EIPE was also supported by literature such as original articles conducted with the help of questionnaires designed specifically for studies on sport and school involvement (Machado et al., 2007; Peserico et al., 2015; Soares et al., 2015; Maciel et al., 2017), as well as measurement instruments (questionnaires and 
interviews) used in theses and dissertations on this topic (Azevedo, 2014; Correia, 2014).

\section{Ethical aspects}

The study was approved by the Research Ethics Committee of the State University of Santa Catarina (no 2.667.499). All participants were informed about the study objectives and procedures and signed Informed Consent Forms (athletes). The athletes' guardians also signed Informed Consent Forms.

\section{EIPE's validation process}

The EIPE's validation process (Figure 1) was conducted with athletes (both sexes, 13 to 18 years old, students at the secondary and high school levels) from team (basketball, soccer, futsal, handball, volleyball) and individual sports (artistic gymnastics, judo, karate, swimming, taekwondo, tennis, table tennis, chess). The athletes participated in competitions in the state of Santa Catarina/Brazil at regional, state, national and international levels.

Figure 1

EIPE's validation process flowchart

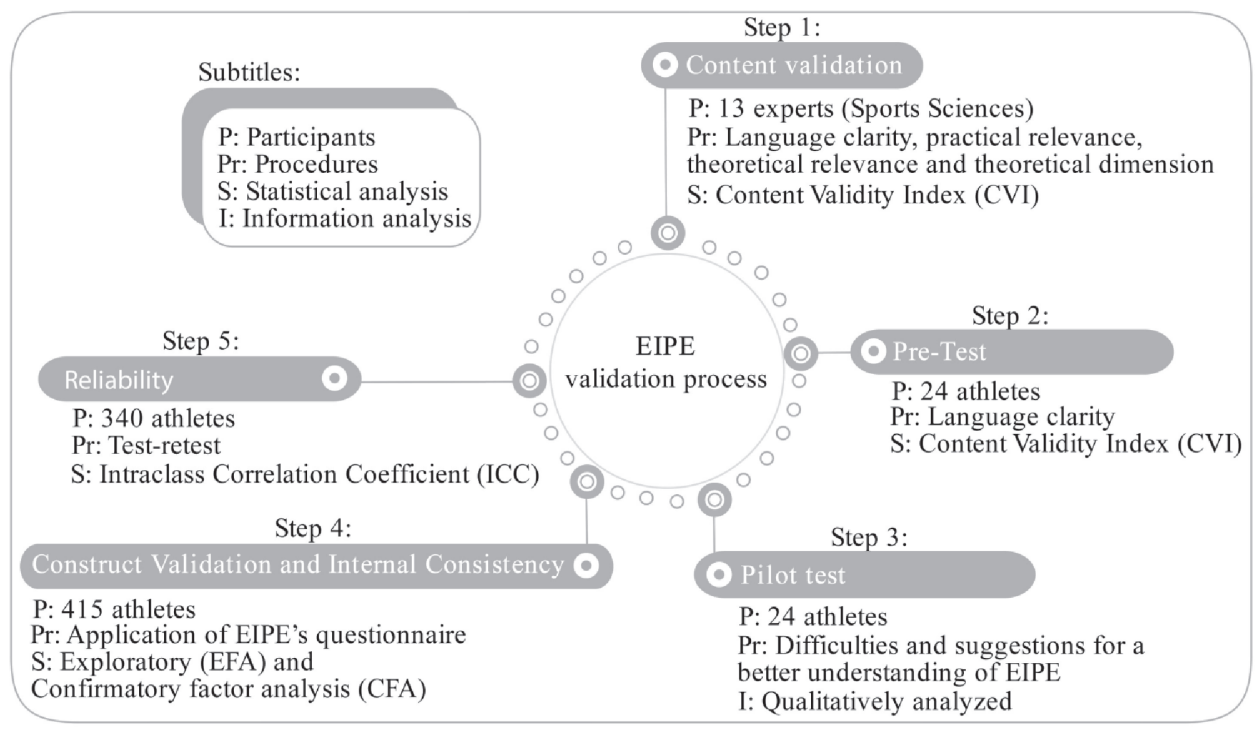

\section{Step 1: Content validation}

Participants. Thirteen experts participated in the content validation, selected according to the following criteria: 1. to be a doctor in Physical Education in Brazil; 2. to work or have worked as a professor in Higher Education; 3. to work or have worked as a teacher in School Physical Education and/or in sports clubs; 4. to be a researcher and have publications in the field of sports and/or school education; 5 . to have publications related to the development and validation of measurement instruments. Among the experts included, five did not meet the fifth criterion and one did not meet the third criterion. All experts were able to participate in the validation process, corroborating the recommendation that experts should meet at least $80 \%$ of the established criteria (Voutilainen, \& Liukkonen, 1995).

Procedures. The experts assessed the EIPE based on the following dimensions: (a) language clarity; (b) practical relevance; (c) theoretical relevance; and (d) theoretical dimension (Cassepp-Borges et al., 2010). The experts assigned values ( 1 - inadequate, 2 - unsuitable, 3 - acceptable, 4 - adequate and 5 - very adequate) to assess each item on language clarity, practical relevance, and theoretical relevance. In the theoretical dimension, they assigned letters corresponding to their opinion about the items and the dimension to which they were linked (A - personal influences, B - family influences, $\mathrm{C}$ - coach influences, D - teammates influences). If an item needed to be reformulated, the expert should detail some suggestions for its improvement.

Statistical analysis. The Content Validity Index (CVI) was determined through Aiken's V coefficient, based on the equation modified by Penfield and Giacobbi (2004), with the aid of the Visual Basic Program (version 6.0), developed by Merino and Livia (2009). The minimum acceptable value for content validation was determined from the number of experts $(.67 ; p=.48)$ (Aiken, 1985) using the $95 \%$ confidence interval (CI) (Merino, \& Livia, 2009). The measure of agreement among the experts regarding the EIPEs' theoretical dimensions was obtained from the Kappa's coefficient (95\% CI for fixed-marginal multirate [.92 .95]) (Randolph, 2005; Warrens, 2010), using the Gwet (2010) variation formula. 


\section{Step 2: Pre-Test (language clarity)}

Participants. To assess the EIPE's language clarity, 12 athletes from team sports and 12 athletes from individual sports (six boys and six girls from 13 to 18 years old) were randomly selected according to the availability of clubs and the athletes themselves. Athletes should also be secondary or high school students.

Procedures and data collection. The athletes assessed the EIPE's items based on a scale from 1 (not clear) to 5 (clear), regarding language clarity. The instrument also provided open spaces for the athletes to indicate possible suggestions for each item. Data collection was performed before or after a typical sports training session. At the time of collection, the main researcher (first author) was available to answer any athletes' questions. The average pre-test completion time was 18 minutes.

Statistical analysis. Pre-test CVI was determined by Aiken's V coefficient, based on the number of athletes selected $(.64 ; p=.35)$ and 95\% CI (Aiken, 1985; Merino, \& Livia, 2009).

\section{Step 3: Pilot test}

Participants. In this stage, 24 athletes were randomly selected according to the same criteria adopted in step 2 (pre-test). The pilot test was performed with participants who had not yet participated in the previous stage.

Procedures and data collection. The pilot test was performed before or shortly after a typical sports training session. The main researcher was available during the instrument completion to answer any athletes' questions. There were blank spaces for the athletes to indicate possible difficulties in understanding the items, as well as suggestions for better clarification.

Information Analysis. The results of the pilot test were qualitatively analysed, considering the difficulties and suggestions reported by the athletes.

\section{Step 4: Construct Validation and Internal Consistency}

Participants. The sample consisted of 415 intentionally selected athletes, 124 (29.9\%) females and 291 (70.1\%) males, participating in either team $(78.5 \%)$ or individual sports $(21,5 \%)$. From these, $56.4 \%$ were students in secondary school and $43.6 \%$ were students in high school, aged between 13 to 18 years old (average $=15.3 ; S D=1.49$ ).

Procedures and data collection. Prior contact was made with the athletes and their respective coaches in order to schedule the application of the EIPE. The application was performed by the researchers responsible for the study, accompanied by other previously oriented researchers, at the sports training sites of each modality. Each athlete answered the instrument individually with the presence of the researchers to answer any questions.
Statistical analysis. The EIPE construct validity was performed through exploratory (EFA) and confirmatory factor analysis (CFA), with the aid of IBM SPSS (version 21.0) and AMOS for Structural Equation Modelling (version 23.0) software's. EFA was calculated by using the principal axis factor extraction method, with direct oblique rotation. The Kaiser-Meyer-Olkin (KMO) was used as a sample adequate index for factor analysis, considering scores between .70 and .80 as average, and $\geq .80$ as optimum (Hair et al., 2005). To verify whether the (co) variance matrix was equal to the identity matrix, Bartlett's sphericity test was used to assess the degree of fit of the model to the sample data (Dziuban, \& Shirkey, 1974). To verify the number of factors, the Kaiser-Guttman criteria (eigenvalue >1) (Patil et al., 2007) were used.

The criteria used to maintain the items in the exploratory factor structure were: (a) factor loadings above .30; (b) no items with cross factor; (c) no factor with less than three items (Costello, \& Osborne, 2005). These criteria were employed repeatedly until an acceptable factor solution was obtained. Theoretical definitions regarding the perceived influences on sports and school involvement and performance were considered in the instrument constructs and semantic content in order to define which factor structure solution was most satisfactory. The internal consistency of each factor was obtained from Cronbach's Alpha coefficient $(\alpha>$.70) (Bland, \& Altman, 1997; George, \& Mallery, 2003).

The CFA was used to investigate the model's adequacy model to the empirical data. Because this is the EIPE's first empirical assessment, loads close to or greater than .50 were stipulated, as indicated by the literature (Browne et al., 2002; Kline, 2012). The final model was tested for the following fit quality indicators: (a) Standardized Root-Mean-Square Residual (SRMR) <.06; (b) Chi-Square Ratio $\left(\chi^{2} / d f\right)<.3 .0$; (c) GFI (Goodness of Fit Index) 2.90; (d) AGFI (Adjusted for degrees of freedom) $>.80$; (e) CFI (Comparative fit index) >.90; (f) TLI (Tucker - Lewis index) >.90; (g) RMSEA (Root-square-error of approximation) $<.06$ (Jackson et al., 2009). Internal consistency was obtained through the Cronbach's Alpha coefficient, with a cut-off point of >.70 (Hair et al., 2010).

\section{Step 5: Reliability}

Participants. In this stage, participants were 340 athletes $(29.4 \%$ female and $70.6 \%$ male) from either team $(78.8 \%)$ or individual $(21.2 \%)$ sports. From these, $79 \%$ studied in secondary school and $21 \%$ in high school, aged 13 to 18 years old (average $=15.1 ; S D=5.85$ ).

Procedures and data collection. The EIPE was applied at the training sites in two moments, with an interval of two weeks between the first and second application. Retesting was scheduled immediately after the test. In both applications, leading researchers were present to answer possible questions. 
Statistical analysis. This stage sought to assess the reliability items' and factors' scores of the instrument, which met the criteria established in the previous steps. For the reliability analysis of the scores, the intraclass correlation coefficient (ICC) close to 1 suggested by Nakagawa et al. (2017) was used, adopting 95\% confidence intervals.

\section{Results}

\section{Content validation}

The CVI of each item, determined by Aiken's V coefficient in the content validity stage (language clarity, practical relevance and theoretical relevance), is summarized in Table 1. All the initial proposed items were maintained when confirmed by expert content validation. All items reached values higher than the proposed (.67), and an overall CVI of .90, indicating a high content validity index. The theoretical dimension analysis, performed using the Kappa coefficient, obtained a general index of $95 \%$ and fixed-marginal within the estimated cut-off point (.93), corroborating the satisfactory results at this stage.

Table 1

EIPE's content validation indices

\begin{tabular}{|c|c|c|c|c|c|c|c|c|c|c|}
\hline \multirow{3}{*}{ Items } & \multicolumn{3}{|c|}{ Language clarity } & \multicolumn{3}{|c|}{ Practical relevance } & \multicolumn{3}{|c|}{ Theoretical relevance } & \multirow{3}{*}{$\frac{\mathrm{V}}{\text { Total }}$} \\
\hline & \multicolumn{3}{|c|}{ IC $95 \%$} & \multicolumn{3}{|c|}{ IC $95 \%$} & \multicolumn{3}{|c|}{ IC $95 \%$} & \\
\hline & $\mathrm{V}$ & Min. & Max. & $\mathrm{V}$ & Min. & Max. & $\mathrm{V}$ & Min. & Max. & \\
\hline 1 & .86 & .75 & .93 & .94 & .84 & .98 & .90 & .79 & .96 & .90 \\
\hline 2 & .81 & .68 & .89 & .67 & .54 & .78 & .73 & .60 & .83 & .74 \\
\hline 3 & .92 & .82 & .97 & .94 & .84 & .98 & .92 & .82 & .97 & .93 \\
\hline 4 & .92 & .82 & .97 & .98 & .90 & .00 & .96 & .87 & .99 & .95 \\
\hline 5 & .92 & .82 & .97 & .86 & .75 & .93 & .84 & .72 & .92 & .87 \\
\hline 6 & .84 & .72 & .92 & .88 & .77 & .95 & .90 & .79 & .96 & .87 \\
\hline 7 & .92 & .82 & .97 & .92 & .82 & .97 & .92 & .82 & .97 & .92 \\
\hline 8 & .90 & .79 & .96 & .96 & .87 & .99 & .94 & .84 & .98 & .93 \\
\hline 9 & .88 & .77 & .95 & .84 & .72 & .92 & .90 & .79 & .96 & .87 \\
\hline 10 & .90 & .79 & .96 & .92 & .82 & .97 & .90 & .79 & .96 & .91 \\
\hline 11 & .90 & .79 & .96 & .94 & .84 & .98 & .96 & .87 & .99 & .93 \\
\hline 12 & .84 & .72 & .92 & .83 & .70 & .91 & .83 & .70 & .91 & .83 \\
\hline 13 & .94 & .84 & .98 & .94 & .84 & .98 & .96 & .87 & .99 & .95 \\
\hline 14 & .77 & .64 & .86 & .83 & .70 & .91 & .90 & .79 & .96 & .83 \\
\hline 15 & .90 & .79 & .96 & .94 & .84 & .98 & .90 & .79 & .96 & .91 \\
\hline 16 & .94 & .84 & .98 & .90 & .80 & .96 & .90 & .79 & .96 & .91 \\
\hline 17 & .94 & .84 & .98 & .92 & .82 & .97 & .90 & .79 & .96 & .92 \\
\hline 18 & .92 & .82 & .97 & .94 & .84 & .98 & .92 & .82 & .97 & .93 \\
\hline 19 & .92 & .82 & .97 & .90 & .80 & .96 & .92 & .82 & .97 & .91 \\
\hline 20 & .96 & .87 & .99 & .96 & .87 & .99 & .94 & .84 & .98 & .95 \\
\hline 21 & .83 & .70 & .91 & .83 & .70 & .91 & .86 & .75 & .93 & .84 \\
\hline 22 & .88 & .77 & .95 & .96 & .87 & .99 & .96 & .87 & .99 & .93 \\
\hline 23 & .73 & .60 & .83 & .70 & .56 & .80 & .81 & .68 & .89 & .75 \\
\hline 24 & .94 & .84 & .98 & .96 & .87 & .99 & .94 & .84 & .98 & .95 \\
\hline 25 & .94 & .84 & .98 & .94 & .84 & .98 & .94 & .84 & .98 & .94 \\
\hline 26 & .92 & .82 & .97 & .96 & .87 & .99 & .96 & .87 & .99 & .95 \\
\hline 27 & .92 & .82 & .97 & .90 & .80 & .96 & .83 & .70 & .91 & .88 \\
\hline 28 & .92 & .82 & .97 & .84 & .72 & .92 & .88 & .77 & .95 & .88 \\
\hline 29 & .79 & .66 & .88 & .79 & .66 & .88 & .84 & .72 & .92 & .81 \\
\hline 30 & .94 & .84 & .98 & .92 & .82 & .97 & .88 & .77 & .95 & .91 \\
\hline 31 & .84 & .72 & .92 & .81 & .68 & .89 & .92 & .82 & .97 & .86 \\
\hline 32 & .88 & .77 & .95 & .86 & .75 & .93 & .84 & .72 & .92 & .86 \\
\hline 33 & .90 & .79 & .96 & .86 & .75 & .93 & .92 & .82 & .97 & .89 \\
\hline 34 & .88 & .77 & .95 & .84 & .72 & .92 & .84 & .72 & .92 & .85 \\
\hline 35 & .94 & .84 & .98 & .94 & .84 & .98 & .92 & .82 & .97 & .93 \\
\hline
\end{tabular}


Table 1 (continuation)

EIPE's content validation indices

\begin{tabular}{|c|c|c|c|c|c|c|c|c|c|c|}
\hline \multirow{3}{*}{ Items } & \multirow{2}{*}{\multicolumn{3}{|c|}{ Language clarity }} & \multicolumn{3}{|c|}{ Practical relevance } & \multicolumn{3}{|c|}{ Theoretical relevance } & \multirow{3}{*}{$\begin{array}{c}\mathrm{V} \\
\text { Total }\end{array}$} \\
\hline & & & & & & & & & & \\
\hline & $\mathrm{V}$ & Min. & Max. & $\mathrm{V}$ & Min. & Max. & $\mathrm{V}$ & Min. & Max. & \\
\hline 36 & .90 & .79 & .96 & .86 & .75 & .93 & .90 & .79 & .96 & .89 \\
\hline 37 & .92 & .82 & .97 & .86 & .75 & .93 & .90 & .79 & .96 & .89 \\
\hline 38 & .90 & .79 & .96 & .88 & .77 & .95 & .92 & .82 & .97 & .90 \\
\hline 39 & .83 & .70 & .90 & .92 & .82 & .97 & .92 & .82 & .97 & .89 \\
\hline 40 & .86 & .75 & .93 & .84 & .72 & .92 & .84 & .72 & .92 & .85 \\
\hline 41 & .94 & .84 & .98 & .96 & .87 & .99 & .96 & .87 & .99 & .95 \\
\hline 42 & .92 & .82 & .97 & .84 & .72 & .92 & .92 & .82 & .97 & .89 \\
\hline 43 & .96 & .87 & .99 & .98 & .90 & 1.00 & .98 & .90 & 1.00 & .97 \\
\hline 44 & .94 & .84 & .98 & .88 & .77 & .95 & .92 & .82 & .97 & .91 \\
\hline 45 & .88 & .77 & .95 & .94 & .84 & .98 & .92 & .82 & .97 & .91 \\
\hline 46 & .92 & .82 & .97 & .92 & .82 & .97 & .88 & .77 & .95 & .91 \\
\hline 47 & .94 & .84 & .98 & .96 & .87 & .99 & .94 & .84 & .98 & .95 \\
\hline 48 & .90 & .79 & .96 & .92 & .82 & .97 & .90 & .79 & .96 & .91 \\
\hline 49 & .86 & .75 & .93 & .96 & .87 & .99 & .92 & .82 & .97 & .91 \\
\hline 50 & .92 & .82 & .97 & .94 & .84 & .98 & .96 & .87 & .99 & .94 \\
\hline 51 & .94 & .84 & .98 & .94 & .84 & .98 & .92 & .82 & .97 & .93 \\
\hline 52 & .90 & .79 & .96 & .86 & .75 & .93 & .92 & .82 & .97 & .89 \\
\hline 53 & .90 & .77 & .96 & .92 & .82 & .97 & .88 & .77 & .95 & .90 \\
\hline 54 & .92 & .82 & .97 & .90 & .79 & .96 & .96 & .87 & .99 & .93 \\
\hline 55 & .83 & .70 & .91 & .83 & .70 & .90 & .84 & .72 & .92 & .83 \\
\hline 56 & .90 & .79 & .96 & .88 & .77 & .95 & .90 & .79 & .96 & .89 \\
\hline 57 & .94 & .84 & .98 & .92 & .82 & .97 & .90 & .79 & .96 & .92 \\
\hline 58 & .92 & .82 & .97 & .92 & .82 & .97 & .92 & .82 & .97 & .92 \\
\hline 59 & .92 & .82 & .97 & .92 & .82 & .97 & .92 & .82 & .97 & .92 \\
\hline 60 & .92 & .82 & .97 & .90 & .79 & .96 & .92 & .82 & .97 & .91 \\
\hline 61 & .94 & .84 & .98 & .86 & .75 & .93 & .94 & .84 & .98 & .91 \\
\hline 62 & .96 & .87 & .99 & .96 & .87 & .99 & .94 & .84 & .98 & .95 \\
\hline 63 & .94 & .84 & .98 & .88 & .77 & .95 & .86 & .75 & .93 & .89 \\
\hline 64 & .94 & .84 & .98 & .92 & .82 & .97 & .90 & .79 & .96 & .92 \\
\hline Total & .90 & .79 & .96 & .90 & .79 & .95 & .90 & .80 & .96 & .90 \\
\hline
\end{tabular}

Note. V: content validity index; 95\% CI: 95\% confidence interval

\section{Pre-test (language clarity)}

The results determined by Aiken's V coefficients exceeded the value proposed in all items (.64), obtaining an overall index of $.95(95 \% \mathrm{CI}$; $\min =.88$; $\max =$ $.98)$ that emphasized athletes' satisfactory understanding regarding the EIPE's content.

\section{Pilot test}

Athletes considered the EIPE easy to understand and answer. Only three athletes considered it necessary to reduce the number of items, as they consider the instrument very extensive. Two athletes indicated that some items were very similar to each other. The average time to complete the pilot test was 15 minutes.

\section{Construct validation and internal consistency}

\section{Exploratory Factor Analysis (EFA)}

In general, EFA indicated that the EIPE presented a two-factor structure $(\mathrm{KMO}=.919, p<.001$; explained variance $=35.10 \% ; \alpha=.943$; and correlation matrix ranging from .325 and -.709). The factor 'Involvement in sports training and sports performance in competitions' was composed of 26 items $(\alpha=.916$; eigenvalue $=13.24$; explained variance $=27.02 \%$, while the factor 'Involvement in studies and school performance' had 23 items $(\alpha=.911$; eigenvalue $=3.95$; explained variance $=8.07 \%$ ). Thus, 15 items were excluded due to 
low factor load or cross factor load with similar values $(8,12,20,26,28,30,33,35,38,57,58,61,62,63,64)$ and a new analysis was carried out, confirming the final structure presented.

\section{Confirmatory Factor Analysis (CFA)}

Based on EFA evidence, CFA was carried out. In the initial model (M1), most items obtained factorial loads close to or above .5. However, the modification indices suggested covariance between the measurement errors of some items. The covariance between errors $(r<.3)$ occurred between items of the same factor. The initial and final CFA model (M2) adjustment indices can be seen in Table 3 .

Table 2

EIPE's factor loads, and reliability obtained in EFA

\begin{tabular}{|c|c|c|}
\hline \multirow[b]{2}{*}{ Items } & \multicolumn{2}{|c|}{ Factors } \\
\hline & $\begin{array}{l}\text { Involvement in sports training and } \\
\text { performance in sports competitions }\end{array}$ & $\begin{array}{l}\text { Involvement in studies and } \\
\text { school performance }\end{array}$ \\
\hline 1 & .435 & \\
\hline 2 & .392 & \\
\hline 3 & .629 & \\
\hline 4 & .476 & \\
\hline 5 & .625 & \\
\hline 6 & .475 & \\
\hline 7 & .686 & \\
\hline 9 & .690 & \\
\hline 10 & .335 & \\
\hline 11 & .325 & \\
\hline 13 & .636 & \\
\hline 14 & .440 & \\
\hline 15 & .621 & \\
\hline 16 & .549 & \\
\hline 17 & .471 & \\
\hline 18 & .434 & \\
\hline 19 & .462 & \\
\hline 21 & .453 & \\
\hline 22 & .516 & \\
\hline 23 & .672 & \\
\hline 24 & .548 & \\
\hline 25 & .572 & \\
\hline 27 & .440 & \\
\hline 29 & .637 & \\
\hline 31 & .562 & \\
\hline 32 & .571 & \\
\hline 34 & & -.652 \\
\hline 36 & & -.670 \\
\hline 37 & & -.447 \\
\hline 39 & & -.572 \\
\hline 40 & & -.433 \\
\hline 41 & & -.388 \\
\hline 42 & & -.684 \\
\hline 43 & & -.524 \\
\hline 44 & & -.453 \\
\hline 45 & & -.336 \\
\hline 46 & & -.639 \\
\hline 47 & & -.582 \\
\hline 48 & & -.358 \\
\hline
\end{tabular}


Table 2 (continuation)

EIPE's factor loads, and reliability obtained in EFA

\begin{tabular}{ccc}
\hline & & Factors \\
\cline { 2 - 3 } Items & $\begin{array}{c}\text { Involvement in sports training and } \\
\text { performance in sports competitions }\end{array}$ & $\begin{array}{c}\text { Involvement in studies and } \\
\text { school performance }\end{array}$ \\
\hline 49 & -.510 \\
50 & -.790 \\
51 & & -.567 \\
52 & & -.678 \\
53 & & -.550 \\
54 & & -.380 \\
55 & & -.593 \\
56 & & -.350 \\
59 & .916 & -.660 \\
& 13.24 & -.657 \\
\hline$\alpha$ & $27.02 \%$ & .911 \\
Eigenvalues & & 3.95 \\
Variance explained & & $8.07 \%$ \\
\hline
\end{tabular}

Note. $\alpha=$ Cronbach's Alpha.

Table 3

Adjustment Indexes for Confirmatory Factor Analysis of EIPE's Factor Models

\begin{tabular}{lcccccccc}
\hline \multirow{2}{*}{ Two-dimensional model } & \multicolumn{7}{c}{ Adjustment indices } \\
\cline { 2 - 9 } & $\chi^{2} / g l$ & GFI & AGFI & CFI & SRMR & RMR & RMSEA & TLI \\
\hline M1 & 2.988 & .72 & .70 & .72 & .068 & .052 & .068 & .71 \\
M2 & 1.751 & .85 & .82 & .90 & .059 & .046 & .042 & .89 \\
\hline
\end{tabular}

\section{Reliability}

Results confirmed the test-retest reliability and the internal consistency of the EIPE, since all items reached adequate indices $(p<.01)$ and $\alpha=.943$. The items were grouped to determine the stability and reliability of each factor of the instrument (Table 4), which presented high rates for the validation sample.

Table 4

Correlation and internal consistency of EIPE's factors

\begin{tabular}{lcc}
\hline \multicolumn{1}{c}{ Factor } & CCI (IC 95\%) & $\alpha$ \\
\hline Involvement in sports training and performance in competitions & .953 & .956 \\
Involvement in studies and school performance & .927 & .932 \\
\hline
\end{tabular}

Note. ICC - Intraclass Correlation coefficient; 195\% - 95\% Confidence Intervals; $\alpha$ - Cronbach's Alpha Coefficient

\section{Discussion}

The aim of this study was to develop and validate a scale for identifying young athletes' perceptions of influences on their sport and study practices. The evidence obtained in the performed steps presented satisfactory results of validity, reliability, and stability of the instrument.

For the EIPE to be scientifically reproducible and applicable, four validation steps were performed, as suggested by the literature (Cassepp-Borges et al., 2010; Kim, 2009; Drost, 2011). Similar validation methods were employed in the development and validation of measurement instruments in the area of Health and Sports Sciences (Freeman et al., 2011; Monteiro et al., 2018; Guillén et al., 2019).

The CVI of all items, obtained in content validation (language clarity, practical relevance and theoretical relevance), exceeded the proposed reference value available in the literature, demonstrating a high level of acceptance regarding the instrument content, as well as its suitability for measuring what is intended (Aiken, 1985). The values found were similar to those found by García-Martín 
et al. (2016), Martínez-Abellán et al. (2016) and Collet et al. (2019), where the obtained Aiken's V coefficients exceeded the recommended values.

In the theoretical dimension, results revealed almost perfect levels of agreement among the experts regarding the items' classification and dimensions (Landis, \& Koch, 1977; Cassepp-Borges et al., 2010). This result was slightly higher than the one found by Balbim and Vieira (2015), where the indices found revealed substantial agreement between the items and their respective dimensions in the validation of an instrument in the sports context.

The second validation step (pre-test) aimed to expose the instrument to the target population, in order to verify the instrument items could be correctly understood and interpreted by the subjects before its application (Kim, 2009). According to Morgado et al. (2017), the use of methods that consider the opinion of the target audience is fundamental in the process of developing an instrument.

The pilot test is also recommended as an indispensable procedure for the development of measurement instruments (DeVellis, 2016; Morgado et al., 2017). In both stages, no item was modified, and the index obtained was indicative of good internal consistency (George, \& Mallery, 2003). This result highlights the importance of developing items that are easy to understand and make sense to respondents (Selau et al., 2020).

The EIPE's construction had the advantage of reconciling qualitative and quantitative methods. In general, the evidence found reinforce the literature recommendations on the importance of carrying out different steps to ensure the most accurate validity of an instrument (Apa et al., 2014; Marôco, 2014). It is important to note that the construction of a scale is a laborious, intense and complex process. This reinforces the importance of all steps adopted to the EIPE's construction, since they contributed to substantial improvements in the instrument preliminary version.

Despite the evidence found in the qualitative stages of the instrument's validation, the initial model with 64 items did not present satisfactory factor validity in EFA, since the individual parameters of some items did not saturate with their respective factors and the minimum factor load indicated in the literature (Costello, \& Osborne, 2005). It is important to highlight that the process of building an instrument requires the fulfilment of steps that encompasses the theoretical assumptions of the instrument and the opinion of evaluating judges until the application of different statistical tests. Therefore, the association with other validation processes is crucial for the instrument to produce the expected effect (Medeiros et al., 2015).

In this sense, it is clarified that most of the excluded items were related to the influence of teammates on school involvement and performance (8), while the other items did not demonstrate a pattern that could be theoretically explained. Thus, the decision of excluding the items was due to the understanding that many athletes may not study with their sporting colleagues and, as a consequence, do not provide answers that could contribute to the final result of the instrument score. In addition, although all items were important, the exclusion of items with low factor loads did not affect the final understanding of the instrument.

Soon after the removal of unsatisfactory items, a version of 49 items was tested, which yielded acceptable results (moderate to strong) of internal consistency and correlation between factors (Hair et al., 2005; Jackson et al., 2009). Similar correlations were observed in the dimensions of the Interpersonal Support Assessment List (Cohen et al., 1985) and the Perceived Available Sport Questionnaire (Freeman et al., 2011).

The evidence found in CFA confirmed the two-factor model, revealing the adequacy of the empirical data to the theoretical model. Similar results were found in other sports configuration instruments (Guillén et al., 2019; Monteiro et al., 2018). Although some indices were not entirely satisfactory, it is understood that the evidence found based on the adjustment indices remained very close to the indices considered adequate.

In this case, as already established by the literature in the area, even if certain indices are not within the cutoff point, there is no reason to be disregarded, as long as they are very close to the indices considered satisfactory (Jackson et al., 2009). Thus, the EIPE adjustment indices reached or approached the values indicated by the literature, demonstrating the general adequacy of the model in two factors and confirmatory factor validity (O'Rourke, \& Hatcher, 1994; Hu, \& Bentler, 1999; Jackson et al., 2009).

The reliability analysis, performed through the CCI, showed adequate indices of validity and internal consistency among the instrument's factors (Nakagawa et al., 2017). This data reinforces the significant and positive relationship between the two applications of the instrument and strengthens the its reliability. A similar result was found in the test-retest validation of the Youth Motivational Climate Questionnaire in Youth Sports (Ntoumanis, \& Vazou, 2005) and the Temporal Invariance of the Utrecht Work Engagement Scale (UWES) (Porto-Martin et al., 2020).

The final EIPE's structure model (49 items) differed from the initial model (64 items) due to the exclusion of 15 items during the factor analysis, making the instrument more coherent and lean for data collection. Based on the evidence found, it can be concluded that the results presented in this article showed good psychometric properties, revealing that EIPE is valid and reliable for identifying young athletes' perceptions of influences in both sports and study practices. 
Despite the evidence presented, it is necessary to understand that this is a preliminary EIPE's validation process, so more tests with different types of analysis still need to be performed. In addition, some limitations must be considered, such as the fact that the data was collected only at a certain time of the year.

Future studies may analyse the EIPE's reliability in periods before and after the sports seasons, and in certain semesters and/or academic periods. Likewise, it would be interesting to apply the EIPE in other contexts/countries, since each one has its own sporting and schooling settings. Finally, one should consider the validation of this instrument with a greater number of athletes and other sports, such as cycling, rhythmic gymnastics, beach volleyball and rugby, for example.

\section{Acknowledgments}

There are no mentions.

\section{Financing}

Funding for preparation and production of the study (data collected, data analysis, data interpretation, and writing the results in the present in the manuscript) were obtained by the Coordination for the Improvement of Higher Education Personnel (CAPES) and by the Research Support Foundation and Innovation of the
State of Santa Catarina (FAPESC/UDESC), under the number PAP2019031000011.

\section{Author contributions}

We declare that all authors participated in the elaboration of the manuscript. Specifically, the authors Larissa FP Maciel, Alexandra Folle, Ricardo T. Quinaud participated in the initial writing of the study - conceptualization, research, visualization. Larissa F.P. Maciel, William das N. Salles, Ricardo T. Quinaud, Mônica C. Flach, participated in the data analysis. The authors Larissa F. P. Maciel, William das N. Salles, Ricardo T. Quinaud, Alexandra Folle, Juarez V., do Nascimento participated in the final writing of the work, proofreading and editing.

\section{Availability of data and materials}

All data and syntax generated and analyzed during this research will be treated with complete confidentiality due to the Ethics Committee for Research in Human Beings requirements. However, the dataset and syntax that support the conclusions of this article are available upon reasonable request to the principal author of the study.

\section{Conflict of interests}

The authors declare that there are no conflicts of interest.

\section{References}

Aiken, L. R. (1985). Three coefficients for analyzing the reability and validity of ratings. Educational and Psychological Measurement, 45(1), 131143. http://doi.org/10.1177/0013164485451012

American, P. A., American, E. R. A., \& National, C. M. E. [APA, AERA, \& NCME]. (2014). Standards for educational and psychological testing. American Educational Research Association.

Azevedo, M. F. (2014). Conciliações entre Formação Esportiva e Formação Escolar: Um Estudo das Seleções Brasileiras Masculinas de Basquetebol de Base. [Dissertação de mestrado, Universidade Federal do Espírito Santo]. Universidade Federal do Espírito Santo. http://repositorio.ufes. br/handle/10/1308

Balbim, G., M. \& Vieira, L. F. (2015). Validação para a população brasileira da Escala de Dominância Télica (TDS) no contexto esportivo. Revista Brasileira de Educação Física e Esporte, 29(4), 641-651. http://doi.org/10.1590/1807-55092015000400641

Bland, J. M., \& Altman, D. G. (1997) Statistics Notes: Cronbach’s Alpha. British Medical Journal, 314(7080), 572. http://doi.org/10.1136/ bmj.314.7080.572

Browne, M. W., MacCallum, R. C., Kim, C. T., Andersen, B., L. \& Glaser, R. (2002). When fit indices and residuals are incompatible. Psychological methods, 7(4), 403-421. http://doi.org/10.1037//1082-989x.7.4.403

Carreres-Ponsoda, F., Escartí, A., Cortell-Tormo, J. M., Fuster-Lloret, V., \& Andreu-Cabrera, E. (2012). The relationship between out-ofschool sport participation and positive youth development. Journal of Human Sport and Exercise, 7(3), 671-683. http://doi.org/10.4100/ jhse.2012.73.07

Cassepp-Borges, V., Balbinotti, M. A. A., Teodoro, M. L. M., \& Pasquali, L. (2010). Tradução e Validação de conteúdo: Uma proposta para adaptação de instrumentos. Em L. Pasquali et al. (Orgs.), Instrumentação Psicológica: Fundamentos e Práticas (pp.506-520). Artmed.

Collet, C., Nascimento, J. V., Folle, A., \& Ibáñez, S. J. (2019). Construcción y validación de un instrumento para el análisis de la formación deportiva en voleibol. Cuadernos de Psicología del Deporte, 19(1), 76-89. http://dx.doi.org/10.6018/analesps.29.3.178511

Correia, C. A. J. (2014). Entre a profissionalização a escolarização: Projetos e campo de possibilidades em jovens atletas do Colégio Vasco da Gama. [Dissertação mestrado, Universidade Federal do Rio de Janeiro]. Universidade Federal do Rio de Janeiro. https://ppge.educacao.ufrj. br/Disserta\%C3\%A7\%C3\%B5es2014/dcarlusaugustus.pdf

Costello, A. B., \& Osborne, J. W. (2005). Best practices in exploratory factor analysis: Four recommendations for getting the most from your analysis. Practical Assessment, Research and Evaluation, 10(7), 1-9. https://doi.org/10.7275/jyj1-4868

Côté, J., Baker, J., \& Abernethy, B. (2003). From play to practice: a developmental framework for the acquisition of expertise in team sport. In J., Starkes, \& K. A., Ericsson (Eds.), Expert Performance in Sports: Advances in Research on Sport Expertise (pp. 89-113). Human Kinetics. 
Cohen, S., Mermelstein R., Kamarck, T., \& Hoberman, H. M. (1985). Measuring the Functional Components of Social Support. Em I. G., Sarason, \& B. R., Sarason (Eds.), Social Support: Theory, Research and Applications (pp. 73-94). Springer.

Cutrona, C. E., \& Russel, D. (1990). Type of social support and specific stress: toward a theory of optimal matching. Em B. R., Sarason, I. G., Sarason, \& G. R., Pierce (Eds.). Wiley Series on Personality Processes. Social Support: An Interactional View (pp. 319-366). John Wiley \& Sons.

Cutrona, C. E., \& Russell, D. W. (1987). The provisions of social relationships and adaptation to stress. Em W. H., Jones, \& D., Perlman (Eds.), Advances in Personal Relationships (pp. 37-67). JAI Press.

DeVellis, R. F. (2016). Scale Development: Theory and Applications. Sage Publications.

Drost, E. A. (2011). Validity and reliability in social science research. Education Research and Perspectives, 38(1), 105-123. https://eric. ed.gov/?id=EJ942587

Dziuban, C. D., \& Shirkey, E. C. (1974). When is a correlation matrix appropriate for factor analysis? Some decision rules. Psychological Bulletin, 81(6), 358-361. https://doi.org/10.1037/h0036316

Freeman, P., Coffee, P., \& Rees, T. (2011). The PASS-Q: the perceived available support in sport questionnaire. Journal of Sport and Exercise Psychology, 33(1), 54-74. https://doi.org/10.1123/jsep.33.1.54

García-Martín, A., Antúnez, A., \& Ibáñez, S. J. (2016). Análisis del proceso formativo en jugadores expertos: validación de instrumento. Revista Internacional de Medicina y Ciencias de la Actividad Física y el Deporte, 16(61), 157-182. https://doi.org/10.15366/rimcafd2016.61.012

George, D., \& Mallery, P. (2003). Spss for Windows Step by Step: A Simple Guide and Reference. Allyn \& Bacon.

Gomes, A. R., \& Zão, D. V. (2007). Envolvimento parental e orientação motivacional na prática desportiva: Desenvolvimento de instrumentos de avaliação e análise das percepções de pais e atletas. Psicologia: Teoria, Investigação e Prática, 12(2), 319-339. http://repositorium.sdum. uminho.pt/handle/1822/8238

Guillén, F., Feltz, D., Gilson, T., \& Dithurbide, L. (2019). Psychometric properties of the Spanish version of the Referee Self-Efficacy Scale (REFS). Revista de Psicologia del Deporte, 28(1), 15-24. https://accedacris.ulpgc.es/bitstream/10553/75554/1/revpsidep_ a2019v28n1p15.pdf

Gwet, K. L. (2010). Manual de Confiabilidade entre Avaliadore. Advanced Analytics.

Hair, J. F., Anderson, R. E., Tatham, R. L., \& Black, W. C. (2005). Análise Multivariada de Dados. Bookman.

Hair, J. F., Black, W. C., Babin, B. J., \& Anderson, R. E (2010). Multivariate Data Analysis. Prentice Hall.

Hernández-Sampieri, R., Fernández-Collado, C., \& Baptista-Lucio, M. P. (2014). Metodología de la Investigación. Mc Graw Hill Education.

Holt, N. L., \& Dunn, J. G. H. (2004). Toward a grounded theory of the psychosocial competencies and environmental conditions associated with soccer success. Journal of Applied Sport Psychology, 16(3), 199-219. https://doi.org/10.1080/10413200490 437949

Hu, L. T., \& Bentler, P. M. (1999). Cut-off criteria for fit indices in covariance structure analysis: Conventional criteria versus new alternatives. Structural Equation Modeling: A Multidisciplinary Journal, 6(1), 1-55. https://doi.org/10.1080/10705519909540118

Jackson, D. L., Gillaspy, J. A., \& Purc-Stephenson, R. (2009). Reporting Practices in Confirmatory Factor Analysis: An Overview and Some Recommendations. Psychological Methods, 14(1),6-23. https://doi.org/10.1037/a0014694

Jowett, S., \& Ntoumanis, N. (2004). The Coach-Athlete Relationship Questionnaire (CART-Q): development and initial validation. Scandinavian Journal of Medicine Science in Sports, 14(4), 245-57. https://doi.org/10.1111/j.1600-0838.2003.00338.x

Kim, Y. (2009). Validation of psychometric research instruments: The case of information Science. Journal of the America Society for Information Science and Technology, 60(6), 1178-1191. https://doi.org/10.1002/asi.21066

Kline, R. B. (2012). Assumptions in structural equation modeling. Em R. H., Hoyle (Ed.), Handbook of Structural Equation Modeling (pp. 111-125). The Guilford Press: New York.

Landis, J. R., \& Koch, G. G. (1977). The measurement of observer agreement for categorical data. Biometrics, 33(1), 159-74. https://doi. org $/ 10.2307 / 2529310$

Lee, M. J., \& MacLean, S. (1997). Sources of parental pressure among age group swimmers. European Journal of Physical Education, 2(2), 167177. https://doi.org/10.1080/1740898970020204

Machado, P. X., Cassep-Borges, V., Dell'Aglio, D. D., \& Koller, S. H. (2007). O impacto de um projeto de educação pelo esporte no desenvolvimento infantil. Revista Brasileira de Psicologia Escolar e Educacional, 11(1), 129-143. https://doi.org/10.1590/S141385572007000100006

Maciel, L. F. P., Folle, A., Souza, P. H. X., Vaz, G., \& Salles, W. N. (2017). Envolvimento esportivo e escolar: percepções de alunos-atletas do Programa "Basquetebol Para Todos". Revista Brasileira de Ciência e Movimento, 25(4), 1-12. http://dx.doi.org/10.18511/rbcm.v25i4.7776

Marôco, J. (2014). Análise de Equações Estruturais: Fundamentos Teóricos, Software \& Aplicações. Report Number.

Martínez-Abellán, A., Conesa-Ros, E., Morán-Navarro, R., Pallarés, J. G., de la Cruz-Sánchez, E., Ortega, E., \& López-Gullón, J. M. (2016). Diseño y validación de contenido de un cuestionario sobre Pérdida de Peso en Deportes de Combate (PPDC). Cuadernos de Psicología del Deporte, 16(3), 113-122. https://scielo.isciii.es/pdf/cpd/v16n3/ ciencias_deporte4.pdf

Medeiros, R. K. S., Ferreira Júnior, M. A., Pinto, D. P. S., Vitor, A. F., Santos, V. E. P., \& Barichello, E. (2015). Modelo de validação de conteúdo de Pasquali nas pesquisas em Enfermagem. Revista de Enfermagem Referência, 4(4), 127-135. http://dx.doi.org/10.12707/ RIV14009

Merino, C. S., \& Livia, J. S. (2009). Intervalos de confianza asimétricos para el índice la validez de contenido: Un programa Visual Basic para la V de Aiken. Anales de Psicología, 25(1), 169-171. https://www.redalyc.org/articulo.oa?id=16711594019

Milistetd, M., Mesquita, I., Nascimento, J. V., \& Sobrinho, A. E. P. S. (2008). Concepções dos treinadores acerca do papel da competição na formação desportiva de jovens jogadores de voleibol. Journal of Physical Education, 19(2), 151-158. http://doi.org/10.4025/reveducfis. v19i2.3324

Monteiro, D., Moutão, J., \& Cid, L. (2018). Validation of the Behavioural Regulation in Sport Questionnaire in Portuguese athletes. Revista de Psicologia del Deporte, 27(1), 145-150. https://repositorio.ipsantarem.pt/handle/10400.15/2108

Morgado, F., Meireles, J., Neves, C., Amaral, A., \& Ferreira, M. (2017). Scale development: Ten main limitations and recommendations to improve future research practices. Psicologia: Reflexão e Crítica, 30(1), 1-20. https://doi.org/10.1186/s41155-016-0057-1

Nakagawa, S., Johnson, P. C., \& Schielzeth, H. (2017). The coefficient of determination R2 and intra-class correlation coefficient from generalized linear mixed-effects models revisited and expanded. Journal of The Royal Society Interface, 14(134), 1-11. https://doi. org/10.1098/rsif.2017.0213 
Ntoumanis, N., \& Vazou, S. (2005). Peer Motivational Climate in Youth Sport: Measurement Development and Validation. Journal of Sport and Exercise Psychology, 27(4), 432-455. https://doi.org/10.1123/jsep.27.4.432

O'Neill, M., Calder, A., \& Allen, B. (2015). Australian parents' perceptions of the issues faced by their adolescent high-performance sports children in balancing school and sport. Journal of Sports Pedagogy and Physical Education, 6(3), 1-12. https://doi.org/10.18848/2381-7100/ $\mathrm{CGP} / \mathrm{v} 06 \mathrm{i} 03 / 59425$

O'Rourke, N., \& Hatcher, L. (1994). A Step-By-Step Approach to Using the Sas System for Factor Analysis and Structural Equation Modeling. SAS Institute Inc.

Patil, V. H., Singh, S. N., Mishra, S., \& Donavan, D. T. (2007). Parallel Analysis engine to aid determining number of factors to retain [Software]. http://ires.ku.edu / smishra/parallelengine.htm.

Penfield, R. D., \& Giacobbi, P. R. (2004). Applying a Score Confidence Interval to Aiken's Item Content-Relevance Index. Measurement in Physical Education and Exercise Science, 8(4),213-225. https://doi.org/10.1207/s15327841mpee0804_3

Peserico, C. S., Kravchychyn, C., \& Oliveira, A. A. B. (2015). Análise da relação entre esporte e desempenho escolar: um estudo de caso. Revista Pensar a Prática, Goiânia, 18(2), 260-277. https://doi.org/10.5216/rpp.v18i2.27965

Porto-Martin, P. C., Machado, P. G. B., \& Viacava, J. J. C. (2020). Engajamento no Trabalho: Características Psicométricas e Invariância Temporal do UWES. Avaliação Psicológica, 19(3), 277-288. https://dx.doi.org/10.15689/ap.2020.1903.15631.06

Ramey, H. L., \& Rose-Krasnor, L. (2012). Contexts of Structured Youth Activities and Positive Youth Development. Child Development Perspectives, 6(1), 85-91. https://doi.org/10.1111/j.1750-8606.2011.00219.x

Randolph, J. J. (2005, October 14-15). Livre-marginalmultirrato kappa: uma alternativa para o marginal fixo de Fleiss multirratokappa. [Paper presentation]. Joensuu University Learning and Instruction Symposium, Joensuu, Finland.

Sarason, I. G., Sarason, B. R., Shearin, E. N., \& Pierce, G. R. (1987). A brief measure of social support: Practical and theoretical implications. Journal of Social and Personal Relationships, 4(4), 497-510. https://doi.org/10.1177/0265407587044007

Selau, T., Silva, M. A., \& Bandeira, D. R. (2020). Construção e Evidências de Validade de Conteúdo da Escala de Funcionamento Adaptativo para Deficiência Intelectual (EFA-DI). Avaliação Psicológica, 19(3), 333-341. http://dx.doi.org/10.15689/ap. 2020.1903.17952.11

Soares, J. A. P., Antunes, H. R. L., \& Aguiar, C. F. S. (2015). Prática desportiva e sucesso de moças e rapazes no ensino secundário. Revista Brasileira de Ciência e Movimento, 37(1), 20-28. https://doi.org/10.1016/j.rbce.2013.06.002

Voutilainen, P., \& Liukkonen, A. (1995). Senior Monitor - Laadun Arviointimittarin Sisällön Validiteetin Määrittäminen. Hoitotiede, 1(1), 51-56. https://www.julkari.fi/ handle/10024/91765? show=full

Warrens, M. J. (2010). Desigualdades entre kappas multi-avaliadores. Avanços na Análise e Classificação de Dados, 4(4), 271-286. https://doi. org/10.1007/s11634-010-0073-4

\section{Supplement A}

EIPE original version

\section{ESCALA DE AVALIAÇÃO DE INFLUÊNCIAS PERCEBIDAS NO ESPORTE E NO ESTUDO (EIPE)}

INSTRUÇõES: Este questionário se refere a como você percebe as influências do seu envolvimento pessoal e dos seus familiares, treinadores e colegas de equipe na sua prática esportiva e nos seus estudos escolares. POR FAVOR, RESPONDA A TODAS AS QUESTÕES.

Tenha em mente que as definições abaixo correspondem a:

Envolvimento com o treinamento esportivo: dedicação, interesse e concentração nos treinamentos (físico, técnico, tático, psicológico); Desempenho em competições esportivas: resultado de sua participação em jogos, torneios, taças, copas e campeonatos;

Envolvimento com os estudos: dedicação, interesse e concentração nos estudos (sua frequência na escola, rotina de estudos fora da sala de aula, realização de cursos de idiomas e informática);

Desempenho escolar: notas ou conceitos escolares obtidos por você.

\begin{tabular}{llll}
\hline \multicolumn{1}{|c|}{ PERCEPÇÕES } & & & \\
& & &
\end{tabular}




\section{Supplement A (continuation)}

\section{EIPE original version}

O incentivo (motivação) que recebo do meu treinador influencia meu envolvimento com o treinamento esportivo de forma...

As cobranças do meu treinador com relação ao esporte influenciam meu envolvimento com o treinamento esportivo de forma..

Minhas metas no esporte influenciam meu envolvimento com o treinamento esportivo de forma...

Minha capacidade de superar as dificuldades enfrentadas no esporte (lesões, derrotas, não convocação, cobranças exageradas) influencia meu envolvimento com o treinamento esportivo de forma...

As orientações esportivas (dicas e conselhos) que recebo do meu treinador influenciam meu envolvimento com o treinamento esportivo de forma...

O incentivo (motivação) que recebo dos meus colegas de equipe influencia meu envolvimento com o treinamento esportivo de forma...

O convívio (treinos, momentos de lazer) com meus colegas de equipe influencia meu envolvimento com o treinamento esportivo de forma..

As orientações esportivas (dicas, conselhos) que recebo dos meus familiares influenciam meu envolvimento com o treinamento esportivo de forma...

Minha dedicação e responsabilidade (disciplina) com o esporte influencia meu desempenho em competições esportivas de forma..

O apoio que recebo dos meus familiares (transporte, materiais esportivos, dinheiro, alimentação, moradia) influencia meu desempenho em competições esportivas de forma...

Minha motivação no esporte influencia meu desempenho em competições esportivas de forma...

( ) ( ) ( ) ( ) ( )

()$\quad() \quad(\quad) \quad(\quad)$

( ) ( ) ( ) ( ) ( )

( ) ( ) ( ) ( ) ( )

()()()()$(~)$

( ) ( ) ( ) ( ) ( )

O apoio que recebo por meio do meu treinador (transporte, materiais esportivos, dinheiro, alimentação, moradia) influencia meu desempenho em competições esportivas de forma...

As cobranças do meu treinador com relação ao esporte influenciam meu desempenho em competições esportivas de forma..

Minhas metas no esporte influenciam meu desempenho em competições esportivas de forma...

A cobrança dos meus familiares com relação ao esporte influencia meu desempenho em competições esportivas de forma...

As orientações esportivas (dicas e conselhos) que recebo do meu treinador influenciam meu desempenho nas competições esportivas de forma...

As orientações esportivas (dicas, conselhos) que recebo dos meus familiares influenciam meu desempenho nas competições esportivas de forma...

As orientações esportivas (dicas e conselhos) que recebo dos meus colegas de equipe influenciam meu desempenho nas competições esportivas de forma...

O apoio que recebo dos meus familiares (transporte, materiais escolares, dinheiro, alimentação, moradia) influencia meu envolvimento com os estudos de forma...

A cobrança dos meus familiares com relação aos estudos influencia meu envolvimento com os estudos de forma...

A bolsa de estudos que recebo com apoio (consentimento) do meu treinador influencia meu envolvimento com os estudos de forma...

Minhas metas escolares influenciam meu envolvimento com os estudos de forma...

( ) ( ) ( ) ( ) ( )

( ) ( ) ( ) ( ) ( )

( ) ( ) ( ) ( ) ( )

( ) ( ) ( ) ( ) ( )

( ) ( ) ( ) ( ) ( )

( ) ( ) ( ) ( ) ( )

( ) ( ) ( ) ( ) ( )

( ) ( ) ( ) ( ) ( )

( ) ( ) ( ) ( ) ( )

( ) ( ) ( ) ( ) ( )

( ) ( ) ( ) ( ) ( )

( ) ( ) ( ) ( ) ( )

( ) ( ) ( ) ( ) ( )

( ) ( ) ( ) ( ) ( )

O incentivo (motivação) que recebo dos meus familiares influencia meu envolvimento com os estudos de forma... ( ) ( ) ( ) ( ) ( )

As cobranças do meu treinador com relação aos estudos influenciam meu envolvimento com os estudos de forma... ( ) ( ) ( ) ( ) ( )

Minha capacidade de superar as dificuldades enfrentadas na escola (notas baixas, reprovação, cobranças

exageradas) influencia meu envolvimento com os estudos de forma..

As orientações nas tarefas escolares que recebo dos meus familiares influenciam meu envolvimento com os estudos de forma...

O incentivo (motivação) que recebo do meu treinador influencia meu envolvimento com os estudos de forma...

O incentivo (motivação) que recebo dos meus colegas de equipe influencia meu envolvimento com os estudos de forma...

As orientações escolares (dicas, conselhos) que recebo do meu treinador influenciam meu envolvimento com os estudos de forma...

$\mathrm{O}$ apoio no deslocamento (carona) que recebo dos meus colegas de equipe influencia meu envolvimento com os estudos de forma...

( ) ( ) ( ) ( )

$\left(\begin{array}{llll}() & (1) & (1)\end{array}\right.$

( ) ( ) ( ) ( ) ( )

( ) ( ) ( ) ( ) ( )

Minha dedicação e responsabilidade (disciplina) com os estudos influencia meu desempenho escolar de forma...

$\mathrm{O}$ apoio que recebo dos meus familiares (transporte, materiais escolares, dinheiro, alimentação, moradia) influencia meu desempenho escolar de forma...

( ) ( ) ( ) ( ) ( )

O incentivo (motivação) que recebo do meu treinador influencia meu desempenho escolar de forma...

$($ ) $($ ) $($ ) ( ) ( )

( ) ( ) ( ) ( ) ( )

Minha motivação para os estudos influencia meu desempenho escolar de forma...

A bolsa de estudos que recebo com apoio (consentimento) do meu treinador influencia meu desempenho escolar de forma...

O incentivo (motivação) que recebo dos meus colegas de equipe influencia meu desempenho escolar de forma...

A cobrança dos meus familiares com relação aos estudos influencia meu desempenho escolar de forma... 


\section{Supplement A (continuation)}

EIPE original version

\begin{tabular}{|c|c|}
\hline $\begin{array}{l}\text { As orientações escolares (dicas, conselhos) que recebo do meu treinador influenciam meu desempenho } \\
\text { escolar de forma... }\end{array}$ & 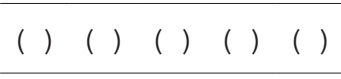 \\
\hline $\begin{array}{l}\text { Minha capacidade de superar as dificuldades enfrentadas na escola (notas baixas, reprovação, cobranças } \\
\text { exageradas) influencia meu desempenho escolar de forma... }\end{array}$ & 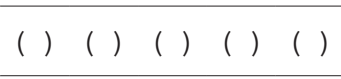 \\
\hline As orientações nas tarefas escolares que recebo dos meus familiares influenciam meu desempenho escolar de forma... & ()()()() \\
\hline As cobranças do meu treinador com relação aos estudos influenciam meu desempenho escolar de forma... & $\left(\begin{array}{llll}() & (\end{array}\right)(\mathbf{~})$ \\
\hline O incentivo (motivação) que recebo dos meus familiares influencia meu desempen & ()$($ ) ( ) ( ) \\
\hline
\end{tabular}

\section{Supplement B}

\section{EIPE score calculation}

Considering the 196 variabilities of the possible scores, as a function of the minimum (49) and maximum response values (245) for the 49 items of the EIPE, this variability was divided by three $(196 / 3=65.34)$. From the sum of the lowest possible score (49) and the result of the division of variability (65.4), the first cut-offs index $(49+65.4=114.4)$ was obtained. The second cut-off index was established from the result of the first cut-off index (114.4) plus the division of variability $(114.4+65.34)$, which resulted in the 179.8 score. Thus, it was determined that scores lower than 114, obtained from the sum of the instrument items, are considered as negative influence, while scores between $115(114+1)$ and 180 are considered indifferent and scores above $181(180+1)$ are considered as positive influence. These calculations were performed for the factors and dimensions, generating the following scores (Tables 1 to 5 ).

Table 1

EIPE general calculation (49 items)

\begin{tabular}{ccc}
\hline Calculation & Scores & Classification \\
\hline $49+65,4=114,4$ & $<114$ & Negative influence \\
$114,4+65,4=179,8$ & entre 115 e 180 & Indifferent \\
$180+1$ & $>181$ & Positive influence \\
\hline
\end{tabular}

Note. study data

Table 2

Calculation by factor (sport - 26 items; study - 23 items)

\begin{tabular}{lcccc}
\hline \multirow{2}{*}{ Classification } & \multicolumn{4}{c}{ Scores } \\
\cline { 2 - 5 } & Calculation & Sport & Calculation & Study \\
\hline Negative influence & $26-135=109 / 3=36+23$ & $<63$ & $23-110=88 / 3=29+23$ & $<51$ \\
Indifferent & $63+36$ & between 64 and 99 & $51+29$ & between 52 and 81 \\
Positive influence & $99+1$ & $>100$ & $81+1$ & $>82$ \\
\hline
\end{tabular}

Note. study data

Table 3

Calculation by factor (sport and study)

\begin{tabular}{lcccc}
\hline \multirow{2}{*}{ Dimensions / Items } & \multicolumn{4}{c}{ Scores } \\
\cline { 2 - 5 } & Calculation & Negative & Indifferent & Positive \\
\hline Personal (14) & $14-70=56 / 3=18+14$ & $<32$ & between 33 and 51 & $>52$ \\
Families (12) & $12-60=48 / 3=16+12$ & $<28$ & between 29 and 44 & $>45$ \\
Coaches (13) & $13-65=52 / 3=17+13$ & $<30$ & between 31 and 48 & $>49$ \\
Teammates (10) & $10-50=40 / 3=13+10$ & $<13$ & between 14 and 17 & $>18$ \\
\hline
\end{tabular}

Note. study data 
Table 4

Calculation by factor (sport)

\begin{tabular}{lcccc}
\hline \multirow{2}{*}{ Dimensions } & \multicolumn{3}{c}{ Scores } \\
\cline { 2 - 5 } & Calculation & Negative & Indifferent & Positive \\
\hline Personal (7) & $7-35=28 / 3=9+7$ & $<16$ & between 17 and 26 & $>27$ \\
Families (7) & $7-35=28 / 3=9+7$ & $<16$ & between 17 and 26 & $>27$ \\
Coaches (5) & $5-25=20 / 3=7+5$ & $<12$ & between 13 and 18 & $>19$ \\
Teammates (8) & $8-40=32 / 3=11+8$ & $<19$ & between 20 and 29 & $>30$ \\
\hline
\end{tabular}

Note. study data

Table 5

Calculation by factor (study)

\begin{tabular}{|c|c|c|c|c|}
\hline \multirow{2}{*}{ Dimensions } & \multicolumn{4}{|c|}{ Scores } \\
\hline & Calculation & Negative & Indifferent & Positive \\
\hline Personal (7) & $7-35=28 / 3=9+7$ & $<16$ & between 17 and 26 & $>27$ \\
\hline Families (5) & $5-25=20 / 3=7+5$ & $<12$ & between 13 and 18 & $>19$ \\
\hline Coaches (8) & $8-40=32 / 3=11+8$ & $<19$ & between 20 and 29 & $>30$ \\
\hline Teammates (2) & $2-10=8 / 3=3+2$ & $<5$ & between 6 and 7 & $>8$ \\
\hline
\end{tabular}

Note. study data

\section{Sobre os autores}

Larissa Fernanda Porto Maciel is professor in MF Basketball School, has Master degree by Movement Sciences at the State University of Santa Catarina (UDESC). She is currently a PhD student in the Graduate Program in Human Movement Sciences (PPGCMH - UDESC).

Mônica Cristina Flach is professor, graduated in Physical Education from the State University of Santa Catarina (UDESC). He is currently a master student in the Graduate Program in Human Movement Sciences (PPGCMH - UDESC).

William das Neves Salles is Physical Education teacher at the Unisociesc International School (Florianópolis) and at the Autonomy School. He holds a Doctorate in Physical Education from the Federal University of Santa Catarina. He is part of the Sports Pedagogy Research Center (NuPPE/CDS/UFSC).

Ricardo Teixeira Quinaud has Master degree in Physical Education by the Federal University of Santa Catarina (UFSC) and he is currently a PhD student in Physical Education at UFSC/SC.

Juarez Vieira do Nascimento is titular professor at DEF/CDS/UFSC, Ph.D. in Sports Science (University of Porto), permanent professor of the Postgraduate Program in Physical Education (PPGEF/UFSC), and researcher linked to the Pedagogy Research Center of Sport (NuPPE/CDS/UFSC).

Alexandra Folle is professor of Physical Education (UNOCHAPECÓ), Ph.D. in Physical Education from the Federal University of Santa Catarina (UFSC). She is currently a professor in the Postgraduate Program in Human Movement Sciences at the State University of Santa Catarina (UDESC).

\section{Como citar este artigo}

Maciel, L. F. P., Flach, M. C., Salles, W. N., Quinaud, R. T., Nascimento, J. V., \& Folle, A. (2021). Development and validation of the Perceived Influences on Sport and Study Assessment Scale. Avaliação Psicológica, 20(3), 274-288. http://dx.doi.org/10.15689/ ap.2021.2003.20861.02 